Dr. sc. Nada TOMOVIĆ

Filozofski fakultet Nikšić

E-mail: nada.tomovic@gmail.com

Stručni rad/Professional article UDK/UDC: 94(497.16)"1988/2017" Rastoder Š. Adžić N. (049.3)

\title{
Šerbo Rastoder, Novak Adžić, MODERNA ISTORIJA CRNE GORE 1988-2017. OD PREVRATA DO NATO PAKTA, KNJ. I-III, Daily Press-Vijesti, Podgorica 2020, 1776 str.
}

Izlaskom iz štampe trotome edicije knjige Moderna istorija Crne Gore 1988-2017. od prevrata do NATO pakta, istaknutih istoričara akademika Šerba Rastodera i magistra Novaka Adžića, crnogorska istoriografija dobila je sveobuhvatnu sintezu svoje prošlosti u proteklih trideset godina. Izdavač su Daily Press Vijesti. Autori su se odlučili da recenti ove edicije budu istaknuta

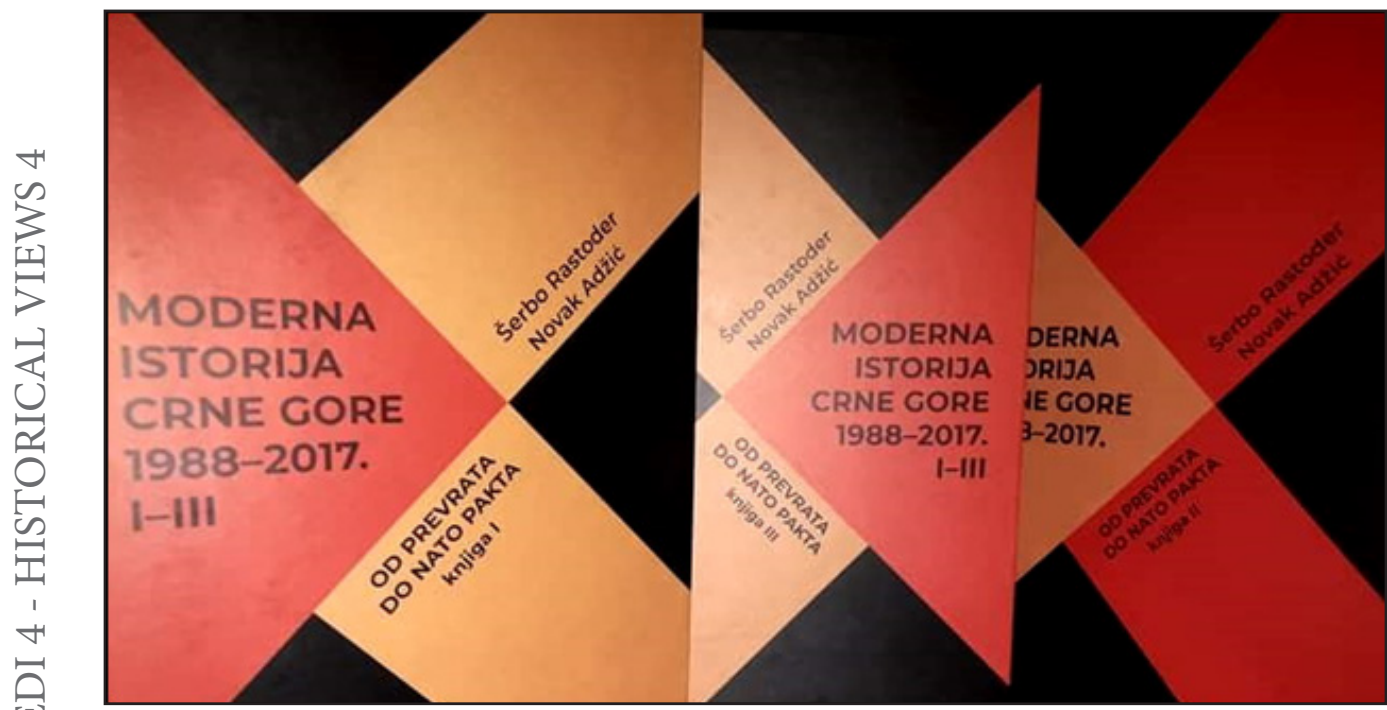

naučna imena ne samo iz Crne Gore već i iz Beograda, Sarajeva, Zagreba i Amsderdama. Shodno tome koja tematika dominira u kojoj od ove tri knjige brižljivo su birani recezenti, i naravno sve istaknute ličnosti iz svoje struke. Tako su recezenti prve knjige: prof. dr. Ilija Vujošević (Podgorica), prof. dr. Husnija Kamberović (Sarajevo), Sonja Biserko (Beograd). Rezenti druge knjige su: Milan Popović (Podgorica), prof. dr. Smail Čekić (Sarajevo), prof. dr. Nevenka Tramp (Amsterdam), dok su recenzenti treće knjige: Latinka Perović (Beograd), prof. dr. Srđan Darmanović (Podgorica) i prof. dr. Hrvoje Klasić (Zagreb). 
Jedan od recenzenata, prof. dr. Milan Popović, ocijenio je ovu ediciju kao ,jedan od najznačajnijih, ako ne i najznačajniji događaj i u nauci i kulturi Crne Gore“. Ova konstatacija dovoljni govori o kakvom kapitalnom djelu se radi. Po prvi put u crnogorskoj istoriografiji crnogorsko društvo u ovom tridesetogodišnjm periodu obrađeno je u totalitetu. Pored burnih političkih dešavanja, analizirane su sve društvene institucije (partije, parlament, sudstvo, vojska, policija), ekonomija, kultura, vjerske prilike. Obrađivati u istorijskom pogledu jedan kratak ali buran period iz bliske crnogorske prošlosti bio je veliki izazov po mnogo čemu. Koristeći toliko izobilje izvora a napraviti pravi odabir slijedeći najsavremeniji metodološki pristup u istorijskoj nauci moralo je rezultirati time da je svaki važan događaj našao mjesto na stranicama ovih knjiga. O kojem izobilju izvora se radi pri pisanju ovih knjiga dovoljno govori broj fus nota, kojih je oko 5.000. Nijedna ličnost koja je imala važnu ulogu kako u političkim dešavanjima, tako i oblasti kulture, ekonomije i drugih sfera djelatnosti nije ostala izostavljena. Pominje se čak oko 3.500 ličnosti koji su bili aktivni sudionici događaja.

Autori su u uvodu prve knjige dali osvrt na položaj Crne Gore u Jugoslaviji u periodu 1945-1989. godine. Detaljnom analizom političkih, socijalnih, kulturnih i prosvjetnih prilika u Crnoj Gori dok je ona bila članica federacije naučna, a i šira čitalačka javnost može izvesti zaključak da li je i u kojoj mjeri socijalno nezadovoljstvo bilo uvod u dešavanja 1988. godine.

Antibirokratska revolucija i prevrat u Crnoj Gori 1988/89. godine obrađena je studiozno i temeljno s posebno detaljnom analizom rastućeg nacionalizma i koliko je taj prevrat bio nacionalno, a koliko politički motivisan.

Kako su tekle pripreme za raspisivanje referenduma o budućem statusu Crne Gore u novostvorenoj zajednici SR Jugoslaviji pitanje je koje privlači posebnu pažnju u ovoj knjizi. Naime, detaljnom analizom brojnih izvora dolazimo do pravog odgovara zašto je referendum o budućem statusu Crne Gore tako brzo raspisan. Pripreme za raspisivanje referenduma bile su prekretnica za podjelu crnogorskog društva na unioniste i konfederaliste. Refleksije tadašnje podjele postoje i danas, samo što je jako bitno napomenuti, da su određeni politički subjekti i istaknute ličnosti koje će decenijama upravljati Crnom Gorom bili zagovornici zajedničke države. Koji su unutrašnjopolitički i spoljnopolitički momenti uticali da bude tako i zašto su pristalice nezavisne države nailazile na otpor vlasti to su ključna pitanja koja se razmatraju u ovoj knjizi. Po prvi put u crnogorskoj istoriografiji imamo tumačenje kolika je bila uloga brojnih medija u ratnohuškačkoj politici ali i dalekovodost pojedinih, istina rijetkih, koji su se usuđivali otvoreno pisati protiv takve pogubne ideologije.

U Crnoj Gori se dio političkih subjekata izrazio protiv rata, zalažući se za mir, te su istaknute javne ličnosti držale mitinge za mir i protestvovali protiv ratnih priprema. Dio rezervista odbio je da se odazove pozivu regrutovanja u JNA. 
Svi oni koji su se izjasnili protiv rata dobijali su etiketu „,izdajnika“. U tome je prednjačio režimsko glasilo Pobjeda. Šta se to desilo sa crnogorskim društvom da je većina političkog vrha koje je vodilo ratnohuškačku politiku napravi otklon od iste i okrene se borbi za nezavisnost Crne Gore detaljno se analizira u sledeće dvije knjige.

Budući da se još aktuelno crnogorsko rukovodstvo hvalilo svojim uspjesima $\mathrm{u}$ vođenju politike $\mathrm{u}$ toku ratnih dešavanja u okruženju da Crna Gora nije učestvovala u ratu u V i VI poglavlju druge knjige opovrgavaju se ove tvrdnje iznošenjem činjenica koje se ne mogu opovrgnuti. Istina, ona je tada bila članica zajednice sa Srbijom i glavne odluke su donošene u Beogradu. Međutim, logično se nameće pitanje da li se mogao napraviti otklon od takve politike. Mnogi intelektualci i opozicioni političari oštro su osuđivali takvu politiku ali nažalost njihovi protesti nisu nailazili na razumijevanje nadležnih. Poglavlje u drugoj knjizi pod naslovom Fašizacija društava privlači posebnu pažnju obzirom na sam naslov. Na prvi pogled preoštra terminologija i neprimjerena za pozne devedesete godine XX vijeka. Ali, nažalost, dovoljno je navesti dvije rečenice akademika Rastodera koji između ostalog kaže: „Radi se o tome da su poraženi nosioci fašizma, ali ne i sama ideja. Ideja se u principu ne može poraziti oružjem, ona se prepoznaje i kao takva prihvata ili odbacuje“ (str. 813). Detaljnom analizom 10 načela fašizma koje je sistematizovao Umberto Eko u svom čuvenom eseju iz 1950. godine i koji mnogi koriste za prepoznavanje ove pojave profesor Rastoder dolazi do zaključka da je tih devedestih godina došlo do fašizacije crnogorskog društva. Nakon ove konstatacije kako i dolikuje ozbiljnim istoričarima ali i teoretičarima slijede dokazi koji utemeljuju navedenu trvdnju. Brojni zločini nad civilinim stanovništvom prije svega islamske vjeroispovijesti, progoni muslimanskih izbjeglica iz Herceg Novog, zločin nad zarobljenicima u logoru Morinj, progon Roma iz Danilovgrada, samo su neke od tamnih mrlja iz crnogorske zbilje tih ratnih godina. Odnos vlasti prema neistomišljenicima takođe je tretiran kao jedan od elemenata fašizacije društva.

Činjenice iznesene u poglavlju Ekonomija kao grana rata mnogima aktuelnim političarima se neće dopasti, pogotovo detalji izneseni u vezi sa švercom cigareta kao „osnovnom privrednom granom“ $u$ vremenu sankcija međunarodne zajednice protiv SRJ. Sav taj šverc odvijao se uz saglasnost crnogorske vlasti. Procjenjuje se da je od prodaje švercovanih cigareta živjelo šest do deset hiljada stanovnika u Crnoj Gori. Italijani su 1995. godine ,zvanično procijenili da se na njihovo tržište iz Crne Gore godišnje prošvercuje 1,2 miliona paketa cigareta“ Tokom sankcija (a i kasnije) cigarete su preko Crne Gore švercovane kako u Italiju, tako i u Hrvatsku i druge zemlje. Šverc cigareta imao je određene negativne političke implikacije, ne samo u domaćoj i inostranoj javnosti, već i u diplomatskim krugovima pojedinih država u pogledu imidža oficijelne Crne Gore. O švercu cigareta u Crnoj Gori pisao je i američki ambasador u SRJ i SCG Vilijem Montgomeri u svojim memoarima Kad ovacije utihnu. U potpoglavlju navedenih memoara pod naslovom Šverc cigareta. 
U trećoj knjizi autori su akcenat stavili na uvođenje višepartijskog sistema u Crnoj Gori, izborima, kampanjama koje su pratile izbore, raskol u vladajućoj Demokratskoj partiji socijalista.

Posebnu pažnju privlači poglavlje Crna Gora $i$ mirovni pregovori u Rambujeu i Parizu 1999. godine. Neučestvovanje Crne Gore na mirovnoj konferenciji o Kosovu, koja je održana u Rambujeu kod Pariza bio je kako ističu autori dokaz potčinjenosti Crne Gore u državnoj zajednici sa Srbijom i dokaz da je ona, uprkos protivljenju crnogorskih vlasti, i dalje bila talac režima predsjednika SRJ Slobodana Miloševića, koji je odlučivao o pitanjima rata i mira na prostoru cijele zemlje, a time i o sudbini Crne Gore. Zašto je onda, i koji su to faktori bili presudni da Crna Gora i pored tako inferiornog položaja u državnoj zajednici ostala u istoj do 2006. godine su pitanja koja su studiozno obrađena i autori daju analizu mnogih prekretnica u razvojnom putu crnogorskog društva ka sticanju nezavisnosti.

Zašto je crnogorsko rukovodstvo dugo ideološki lutalo i zašto su isti oni koji su su donedavno bili zagovornici državne zajednici sa Srbijom postali zagovornici nezavisnosti, u kakvoj političkoj atmosferi je sproveden referendum neka su od pitanja iz bliže crnogorske prošlosti na koja po prvi put izlaskom ove edicije iz štampe javnost dobija relevantne i nepolitikantske odgovore.

Autori su se odlučili za hronološke odrednice budu 1988. i 2017. godina. Dakle, godina početka tranzicije crnogorskog društva i godina ulaska u NATO, što je označilo opredjeljenje za prozapadni kurs crnogorske politike.

Knjiga (odnosno knjige) veoma su bogate podacima, analizima i zaključcima važnim za razumijevanje dešavanja vezanih za period iz savremene istorije Crne Gore u proteklih trideset godina. Svako od poglavlja iz ove edicije može biti osnova budućim istraživačima za još dublju i studiozniju analizu što su autori i sami više puta istakli.

Na kraju, sa zadovoljstvom ističem da je izlazak iz štampe ove knjige (knjiga) naišao na dosad neviđenu pažnju javnosti, s toga, svima onima koji žele više saznati o ovom turbuletnom periodu crnogorske istorije preporučujem da pročitaju ovo po mnogo čemu kapitalno djelo. 